\title{
Histamine H3 receptor: a novel therapeutic target in alcohol dependence?
}

\section{Saara Nuutinen, Jenni Vanhanen, Tiia Mäki and Pertti Panula*}

Neuroscience Center, Institute of Biomedicine, Anatomy, Faculty of Medicine, University of Helsinki, Helsinki, Finland

Edited by:

Maria Beatrice Passani, Universita' di

Firenze, Italy

Reviewed by:

John C. Crabbe, Oregon Health and

Science University, USA

Ezio Tirelli, Université de Liège,

Belgium

\section{*Correspondence:}

Pertti Panula, Neuroscience Center, Institute of Biomedicine, Faculty of

Medicine, University of Helsinki, $P O B$ 63, 00014 Street Address,

Haartmaninkatu 8, 00290 Helsinki,

Finland.

e-mail:pertti.panula@helsinki.fi
The brain histaminergic system is one of the diffuse modulatory neurotransmitter systems which regulate neuronal activity in many brain areas. Studies on both rats and mice indicate that histamine $\mathrm{H} 3$ receptor antagonists decrease alcohol drinking in several models, like operant alcohol administration and drinking in the dark paradigm. Alcohol-induced place preference is also affected by these drugs. Moreover, mice lacking H3R do not drink alcohol like their wild type littermates, and they do not show alcohol-induced place preference. Although the mechanisms of these behaviors are still being investigated, we propose that $\mathrm{H} 3 \mathrm{R}$ antagonists are promising candidates for use in human alcoholics, as these drugs are already tested for treatment of other disorders like narcolepsy and sleep disorders.

Keywords: histamine, H3 receptor, alcohol, self-administration, reward, conditioned place preference, drinking in the dark, addiction

\section{INTRODUCTION}

Alcohol dependence is a remarkable health risk for the society. More than 60 diseases and injuries resulting in approximately 2.5 million deaths per year worldwide are linked to heavy alcohol drinking (Edwards et al., 2011). The number of current available medications for the treatment of alcohol dependence is limited, and most treatments show only moderate efficacy. Promising results in the treatment of alcohol dependence have been obtained with some existing drugs such as anti-epileptic drug topiramate, antispasmic baclofen, and nausea relieving ondansetrone (Sellers et al., 1994; Addolorato et al., 2002; Johnson et al., 2003). New therapeutic drug targets have also been launched during the last years including cannabinoid receptors, neuropeptide $\mathrm{Y}$, corticotropinreleasing factor, and ghrelin (Kraus et al., 2005; Thorsell et al., 2006; Lowery and Thiele, 2010; Maccioni et al., 2010). Recent findings from our laboratory using various animal models assessing dependence-like alcohol behaviors as well as binge-like alcohol drinking suggest that histamine $\mathrm{H} 3$ receptor could be a potential therapeutic target in the treatment of alcohol dependence (Nuutinen et al., 2010, 2011a,b).

\section{HISTAMINERGIC SYSTEM ALTERATIONS LINKED TO HIGH RISK ALCOHOL CONSUMPTION}

Many modulatory neurotransmitter systems converge on the same neurons in the brain. For example, the actions of acetylcholine, histamine, norepinephrine, and serotonin on human neocortical cells are similar: they all increase spiking by reducing spike-frequency adaptation (McCormick and Williamson, 1989). It is thus not surprising that several transmitters or their respective receptor ligands can have similar effects on neural circuits and behavior. Some of the important systems in drug abuse include the mesolimbic dopamine system and corticostriatal and corticoaccumbal glutamate systems (Koob and Volkow, 2010; Kalivas and Volkow, 2011).
All these brain regions are also innervated by histamine-containing nerve fibers originating from the posterior hypothalamic tuberomamillary nucleus both in rodents and in humans (Panula et al., 1989; Airaksinen et al., 1991; Jin and Panula, 2005). Following release, histamine is mainly inactivated by methylation in the brain to an inactive metabolite tele-methylhistamine, whereas in the peripheral organs oxidation by diamino-oxidase is predominant (Haas and Panula, 2003). Concentrations of tele-methylhistamine have been shown to correlate well with histamine release in the brain. Very few studies have directly analyzed the role of histamine in alcohol-related behaviors in humans, and animal studies have been carried out only recently. In postmortem analysis, histamine and tele-methylhistamine, the first metabolite of histamine, levels are clearly increased in patients who suffered from extensive liver cirrhosis following alcohol abuse (Lozeva et al., 2003). The histamine levels were elevated in both patients with high alcohol consumption and those with no alcohol use. The mechanism is thus most likely related to the highly increased levels of neutral amino acids in the blood circulation, as reviewed earlier for experimental portocaval anastomosis cases (Fogel et al., 2002). In one study on type 1 (late onset, often females, low degree of association with violence) and type 2 (early onset, often males, high degree of association with violence) alcoholics histamine levels were significantly elevated in the gray matter of type 1 alcoholics and the levels of tele-methylhistamine were elevated in type 2 alcoholics indicating that histamine turnover is altered (Alakarppa et al., 2002).

In alcohol-preferring Alko alcohol (AA) rats developed in Finland in 1960s using a two-bottle choice preference selection method (Eriksson, 1968) several aminergic systems are abnormal. They have higher tyrosine hydroxylase activity and higher levels of dopamine and noradrenaline in striatum and limbic regions (Ahtee and Eriksson, 1975), higher serotonin levels in 
many brain areas (Ahtee and Eriksson, 1973), and higher histamine and tele-methylhistamine levels in many brain regions than alcohol non-preferring Alko non-alcohol (ANA) rats (Lintunen et al., 2001). Higher tele-methylhistamine levels indicate also higher histamine release in AA than ANA rats. This high histamine content agrees well with the higher density of histamine-immunoreactive nerve fibers in many regions of the AA rat brain, including nucleus accumbens, septal nuclei, and medial preoptic nucleus. Thus, histamine from the other major storage site of brain histamine, mast cells, is not responsible for the significant difference. Receptor radioligand autoradiography has shown significant differences in histamine $\mathrm{H} 1$ receptor binding throughout the brain of AA and ANA rats. The binding densities in AA rat brain were lower, possibly as a result of high histamine release induced downregulation (Lintunen et al., 2001). H3 receptor radioligand binding is lower in AA than ANA rats in the motor cortex, nucleus accumbens, and CA1 area of the hippocampus. Although similar systematic studies have not been carried out in other rat lines selected for high volunteer alcohol intake, an analysis of histamine content in the cortex of the high alcohol preference (HAP) and low alcohol preference (LAP) rats was not different (Kitanaka et al., 2004). However, the histamine induced phosphoinositide hydrolysis was significantly lower in HAP than LAP rats (Kitanaka et al., 2004).

Rat lines selected for high alcohol sensitivity (alcohol nontolerant, ANT) and low alcohol sensitivity (alcohol tolerant, AT; Rusi et al., 1977) also show distinct differences in histaminergic markers in the brain: the ANT rats have reduced histamine levels in many brain areas, including hypothalamus, septum, cortex, and hippocampus (Lintunen et al., 2002). The alcohol sensitive ANT rats also show higher $\mathrm{H} 3$ receptor agonist-induced guanosine $5^{\prime}$ $\mathrm{O}-\left(3-\left[{ }^{35} \mathrm{~S}\right]\right.$ thio $)$ triphosphate binding, indicative of histamine $\mathrm{H} 3$ receptor activation, in motor cortex, insula, and caudate-putamen (Lintunen et al., 2002). The behavioral effects of H3 receptor ligands on these rats have not been tested, but administration of a suicide inhibitor of the histamine synthesizing enzyme histidine decarboxylase, $\alpha$-fluoromethylhistidine ( $\alpha$-FMH), decreases the performance of these rats in the tilting plane test (Lintunen et al., 2002) suggesting higher sensitivity to alcohol in the absence of histamine. Taken together, these results suggest that there are basal differences in the histamine system markers in these rat lines. However, no mutations in genes directly related to histamine synthesis and metabolism or histamine receptors have been identified.

\section{HISTAMINE H3 RECEPTOR-MEDIATED REGULATION OF ALCOHOL DRINKING}

Alcohol consumption in experimental animals can be measured with different types of drinking models. One of the most widely used paradigms is the two-bottle choice test where animals are given free-choice access to alcohol and non-alcoholic fluid, typically water (Green and Grahame, 2008). Alcohol consumption in this model, however, can be influenced by other factors than pharmacological action of alcohol, such as taste and calories. Thus control studies with sweet, bitter and high caloric fluids are needed. Using a modified prolonged 8-week version of the two-bottle choice we found that the histamine $\mathrm{H} 3$ receptor knockout (H3R $\mathrm{KO}$ ) mice consumed alcohol at concentrations 10 and $20 \%$ significantly less than the wild type animals (Nuutinen et al., 2011a;
Table 1). Control studies with bitter quinine and sweet saccharin revealed no genotype differences. There was no difference between the H3R KO and control mice in water consumption. However, the food consumption in H3R KO mice was lower than in control animals leaving us with a question whether the H3R KO mice simply drink less alcohol since they need less energy?

A more newly described method for alcohol consumption is so called Drinking in the Dark (DID) method where mice are given access to alcohol for a short period of time during their active time of the day (Rhodes et al., 2005). The DID paradigm is a measure of binge-like alcohol drinking and usually C57BL/6J mice are used in this paradigm due to their high alcohol consumption. The method is based on the finding that rodents consume more alcohol during the first couple of hours of their active period of the day (Goldstein and Kakihana, 1977). In line with the two-bottle choice (dependence-like drinking) study we found that the H3R KO mice drank less alcohol than control mice when given a 4-h access to 20\% alcohol in the DID model (Nuutinen et al., 2011a; Table 1). Interestingly, H3R KO mice also consumed less $10 \%$ sucrose than the wild type mice again pointing to the direction that the lower need of calories could be the underlying reason for the lower voluntary alcohol consumption in H3R KO mice. To study this in more detail we used H3R specific ligands in the DID model and found that an H3R antagonist ciproxifan dosedependently inhibited alcohol drinking and H3R agonist immepip increased alcohol consumption in wild type mice (Nuutinen et al., 2011a). Importantly, the consumption of $10 \%$ sucrose, very high in caloric content, was not modified by ciproxifan or immepip pretreatment suggesting that other reasons than a altered need for calories could underlie the change in alcohol consumption following modification of H3Rs. In agreement with our mouse studies, Galici et al. (2011) found that an H3R antagonist JNJ-39220675 (1 and $10 \mathrm{mg} / \mathrm{kg}$ ) inhibits alcohol drinking to a similar extent as naltrexone $(5 \mathrm{mg} / \mathrm{kg})$ in a two-bottle choice test in selectively bred alcohol-preferring $(\mathrm{P})$ rats. Interestingly, water consumption was increased by JNJ-39220675 treatment. JNJ-39220675 also decreased alcohol preference but not alcohol consumption after a 3-day alcohol deprivation period in $\mathrm{P}$ rats. These results suggest that the lack or inhibition of H3R leads to lower alcohol consumption both in mice and rats.

Alcohol drinking can be also studied using self-administration paradigms where an operant response, typically a lever press, is required for the access to drink alcohol. Self-administration models are thought to gauge better the motivation to drink alcohol (Green and Grahame, 2008). Operant alcohol self-administration using oral administration is more commonly used in rats than in mice since mice do not drink alcohol as readily as the rats do with the exception of C57BL/6J mouse strain. Already a decade ago we found that H3R antagonists thioperamide and clobenprobit (Table 2 ) dose-dependently $(1,3,10 \mathrm{mg} / \mathrm{kg}$ for both drugs) decrease operant alcohol self-administration in alcohol-preferring AA rats (Lintunen et al., 2001; Table 1). Treatment with H3R agonist R- $\alpha$-methylhistamine or H1R antagonist mepyramine did not affect alcohol self-administration. Recently researchers at Johnson \& Johnson tested the H3R antagonist JNJ-39220675 (10 and $30 \mathrm{mg} / \mathrm{kg}$ ) in an operant model and found that it significantly reduced lever presses for alcohol (Galici et al., 2011). Thus, data 
Table 1 | Summary of the alterations in alcohol consumption and reward followed by manipulations of the brain histaminergic system.

\begin{tabular}{|c|c|c|c|c|}
\hline Model & Animal line/strain & Drug treatment & Result & Reference \\
\hline Two-bottle choice & Alcohol-preferring $\mathrm{P}$ rats & JNJ-39220675 & Decrease in alcohol drinking & Galici et al. (2011) \\
\hline Drinking in the dark & C57BL/6J & Ciproxifan & Lower alcohol consumption & Nuutinen et al. (2011a) \\
\hline Drinking in the dark & C57BL/6J & Immepip & Increased alcohol consumption & Nuutinen et al. (2011a) \\
\hline Two-bottle choice & H3R KO mice & - & Lower alcohol consumption & Nuutinen et al. (2011a) \\
\hline Drinking in the dark & H3R KO mice & - & Lower alcohol consumption & Nuutinen et al. (2011a) \\
\hline $\begin{array}{l}\text { Two-bottle choice with 3-day } \\
\text { alcohol deprivation }\end{array}$ & Alcohol-preferring $\mathrm{P}$ rats & JNJ-39220675 & Decrease in alcohol preference & Galici et al. (2011) \\
\hline Self-administration & Alcohol-preferring AA rats & Thioperamide & Reduced lever presses for alcohol & Lintunen et al. (2001) \\
\hline Self-administration & Alcohol-preferring AA rats & Clobenprobit & Reduced lever presses for alcohol & Lintunen et al. (2001) \\
\hline Self-administration & Alcohol-preferring AA rats & R- $\alpha$-methylhistamine & Increased lever presses for alcohol & Lintunen et al. (2001) \\
\hline Self-administration & Alcohol-preferring AA rats & Mepyramine & No effect on alcohol lever presses & Lintunen et al. (2001) \\
\hline Self-administration & Alcohol-preferring $\mathrm{P}$ rats & JNJ-39220675 & Reduced lever presses for alcohol & Galici et al. (2011) \\
\hline Conditioned place preference & H3R KO mice & - & $\begin{array}{l}\text { Inhibition of alcohol-induced place } \\
\text { preference }\end{array}$ & Nuutinen et al. (2011a) \\
\hline Conditioned place preference & HDC KO mice & - & $\begin{array}{l}\text { Stronger alcohol-induced place } \\
\text { preference }\end{array}$ & Nuutinen et al. (2010) \\
\hline Conditioned place preference & DBA/2J mice & Ciproxifan & $\begin{array}{l}\text { Inhibition of alcohol-induced place } \\
\text { preference }\end{array}$ & Nuutinen et al. (2011b) \\
\hline Conditioned place preference & 129/Sv mice & Ciproxifan & $\begin{array}{l}\text { Stronger alcohol-induced place } \\
\text { preference }\end{array}$ & Nuutinen et al. (2010) \\
\hline Conditioned place preference & DBA/2J mice & JNJ-10181457 & $\begin{array}{l}\text { Inhibition of alcohol-induced place } \\
\text { preference }\end{array}$ & Nuutinen et al. (2011b) \\
\hline Conditioned place preference & DBA/2J mice & Immepip & $\begin{array}{l}\text { No effect on alcohol-induced place } \\
\text { preference }\end{array}$ & Nuutinen et al. (2011b) \\
\hline
\end{tabular}

HDC KO, histidine decarboxylase knockout; H3R KO, histamine H3 receptor knockout.

from oral self-administration studies support the role of $\mathrm{H} 3 \mathrm{R}$ antagonism in suppressing motivation to drink alcohol.

\section{INHIBITORY ROLE OF HISTAMINE IN ALCOHOL-INDUCED CONDITIONED PLACE PREFERENCE}

Alcohol reward and reinforcement can be also studied using Pavlovian conditioning (Tzschentke, 2007). This approach is advisable to use in parallel with the drinking studies in order to exclude intervening variables such as anxiety (Pohorecky, 1991) or novelty seeking (Cloninger et al., 1988) that might result in altered alcohol drinking. In our laboratory, we are routinely using an unbiased alcohol-induced conditioned place preference (CPP) model in mice originally developed and described by Cunningham et al. (2006). In this model mice are given an alcohol injection paired with an environmental cue (cage floor material) for four to eight times over a period of 2-3 weeks. On alternating days with the alcohol injections mice are given vehicle injections paired with another type of floor material. After the conditioning period mice are tested in a preference test where they can choose between the two cage floor materials. Place preference is indexed by a significant difference in time spent on one of the conditioning cue floors between two groups that have had different cues when conditioned to alcohol. In mice lacking the histamine synthesizing enzyme histidine decarboxylase, the alcohol-evoked CPP was found to be stronger suggesting that the lack of histamine increases the reward and reinforcement by alcohol in mice (Nuutinen et al., 2010; Table 1). Next we used different H3R ligands and found that antagonists ciproxifan $(3 \mathrm{mg} / \mathrm{kg})$ and JNJ-10181457 $(5 \mathrm{mg} / \mathrm{kg})$ totally inhibited the CPP by alcohol in wild type DBA/2J mice (Nuutinen et al., 2011b). Importantly, H3R antagonist ciproxifan did not induce place preference or place aversion alone in $129 / \mathrm{Sv}$ mice suggesting that $\mathrm{H} 3 \mathrm{R}$ antagonism does not produce place aversion or preference per se (Nuutinen et al., 2010). However, studies in other mouse strains and rats and using different H3R antagonists would be important to confirm that the H3R antagonists do not have addictive or aversive properties. The H3R agonist immepip (30 mg/kg; Table 2) did not modulate alcohol-induced CPP (Nuutinen et al., 2011b). We think that this was probably due to the difficulty to increase an already strong place preference. When CPP model was applied to H3R KO mice (C57BL/6J background), we found a complete lack of alcohol-evoked CPP (Nuutinen et al., 2011a). In agreement with the alcohol drinking studies these data suggest that inhibition or lack of H3R leads to loss of alcohol reward.

\section{MECHANISMS UNDERPINNING THE BEHAVIORAL FINDINGS}

Stronger alcohol-induced CPP in HDC KO mice suggests that histamine could be the key neurotransmitter mediating the inhibitory effects since the lack of histamine leads to stronger CPP. The inhibitory effect of H3R antagonists may, however involve other neurotransmitter systems in addition to histamine due to the heteroreceptor function of H3Rs (Schlicker et al., 1994). Interestingly, brain microdialysis studies have shown that H3R antagonists thioperamide and GSK189254 do not affect histamine release in rat 
Table 2 | Examples of drugs used in histamine research and in clinical trials.

\begin{tabular}{|c|c|c|c|c|c|}
\hline & $\begin{array}{l}\text { Mechanism } \\
\text { of action }\end{array}$ & Specificity & $\begin{array}{l}\text { Affinity at human vs. } \\
\text { rat } \mathrm{H} 3 \text { receptor }\end{array}$ & $\begin{array}{l}\text { Use in clinical studies } \\
\text { and possible indication(s) }\end{array}$ & Reference \\
\hline \multicolumn{6}{|l|}{ ANTAGONISTS } \\
\hline \multicolumn{6}{|c|}{ Imidazole-based compounds } \\
\hline Ciproxifan & Inverse agonist & $\mathrm{H} 3 \mathrm{R}$ & $\mathrm{p} K_{\mathrm{i}}=7.0, \mathrm{p} K_{\mathrm{i}}=8.9-9.2$ & No; experimental drug & $\begin{array}{l}\text { Ireland-Denny et al. (2001); } \\
\text { Schnell et al. (2010) }\end{array}$ \\
\hline Clobenpropit & Inverse agonist & H3R/H4R & $\mathrm{p} K_{\mathrm{i}}=9.1-9.3, \mathrm{p} K_{\mathrm{i}}=9.1-9.4$ & No; experimental drug & $\begin{array}{l}\text { Ireland-Denny et al. (2001); } \\
\text { Schnell et al. (2010) }\end{array}$ \\
\hline Thioperamide & Inverse agonist & $\mathrm{H} 3 \mathrm{R} / \mathrm{H} 4 \mathrm{R}$ & $\mathrm{p} K_{\mathrm{i}}=7.1-7.3, \mathrm{p} K_{\mathrm{i}}=7.9-8.1$ & No; experimental drug & $\begin{array}{l}\text { Ireland-Denny et al. (2001); } \\
\text { Schnell et al. (2010) }\end{array}$ \\
\hline \multicolumn{6}{|l|}{ Non-imidazole compounds } \\
\hline ABT-239 & Inverse agonist & H3R & $\mathrm{p} K_{\mathrm{i}}=9.4, \mathrm{p} K_{\mathrm{i}}=8.9$ & No, experimental drug & $\begin{array}{l}\text { Esbenshade et al. (2005); } \\
\text { Cowart et al. (2004) }\end{array}$ \\
\hline Bavisant (JNJ-31001074) & Neutral antagonist? & H3R? & not disclosed & Yes; ADHD, alcoholism & Kuhne et al. (2011) \\
\hline GSK189254 & Inverse agonist & H3R & $\mathrm{p} K_{\mathrm{i}}=9.9 ; \mathrm{p} K_{\mathrm{i}}=9.17$ & $\begin{array}{l}\text { Yes, narcolepsy, } \\
\text { hyperalgesia }\end{array}$ & Medhurst et al. (2007) \\
\hline JNJ-39220675 & Neutral antagonist? & $\mathrm{H} 3 \mathrm{R}$ & $K_{\mathrm{i}}=1.4 \mathrm{nM}, K_{\mathrm{i}}=23 \mathrm{nM}$ & Yes; allergic rhinitis & Galici et al. (2011) \\
\hline Pitolisant (BF2.649) & Inverse agonist & $\mathrm{H} 3 \mathrm{R}$ & $\mathrm{IC}_{50}=5.3 \mathrm{nM}, K_{\mathrm{i}}=17 \mathrm{nM}$ & $\begin{array}{l}\text { Yes; excessive daytime } \\
\text { sleepiness, schizophrenia, } \\
\text { epilepsy }\end{array}$ & Ligneau et al. (2007) \\
\hline \multicolumn{6}{|l|}{ AGONISTS } \\
\hline Immepip & partial agonist & $\mathrm{H} 3 \mathrm{R}$ & $\mathrm{p} K_{\mathrm{i}}=9.6, \mathrm{p} K_{\mathrm{i}}=9.0$ & No; experimental drug & Ireland-Denny et al. (2001) \\
\hline R- $\alpha$-methylhistamine & agonist & H3R & $\mathrm{p} K_{\mathrm{i}}=8.9-9.2, \mathrm{p} K_{\mathrm{i}}=8.6-8.7$ & No; experimental drug & $\begin{array}{l}\text { Ireland-Denny et al. (2001); } \\
\text { Schnell et al. (2010) }\end{array}$ \\
\hline \multicolumn{6}{|c|}{ MODULATORS OF HISTAMINE SYNTHESIS } \\
\hline I-histidine & $\begin{array}{l}\text { precursor of } \\
\text { histamine }\end{array}$ & - & - & No, experimental drug & Verdiere et al. (1975) \\
\hline$\alpha$-fluoromethylhistidine & $\begin{array}{l}\text { inhibitor of histidine } \\
\text { decarboxylase }\end{array}$ & - & - & No, experimental drug & $\begin{array}{l}\text { Kollonitsch et al. (1978); } \\
\text { Garbarg et al. (1980) }\end{array}$ \\
\hline
\end{tabular}

nucleus accumbens or striatum, the central areas in the regulation of reward and reinforcement (Giannoni et al., 2009, 2010). Further, dopamine release seems not to be affected either in these areas. H3R antagonist ABT-239 did not modify dopamine release in striatum (Fox et al., 2005) and GSK189254 had no effect on dopamine release in nucleus accumbens (Giannoni et al., 2010; Table 2). JNJ-39220675 treatment, which was found to inhibit alcohol drinking and self-administration in rats did not change dopamine release per se or affect alcohol-induced release of dopamine (Galici et al., 2011; Tables 1 and 2). However, many of the above-mentioned drugs as well as many other H3R antagonists do increase histamine and dopamine release e.g., in prefrontal cortex (Brioni et al., 2011), another important area of the mesocortico-limbic reward circuit which receives dopaminergic input from the ventral tegmental area and sends glutamatergic projections to striatum and nucleus accumbens (Lasseter et al., 2010). In summary, these results demonstrate that $\mathrm{H} 3 \mathrm{R}$ antagonists affect neurotransmitter release in a region-specific manner and it seems that the inhibitory effect of H3R antagonism on alcohol consumption and CPP is likely to result from the effects of these drugs on neurotransmitter release on brain areas other than striatum and nucleus accumbens.

Another intriguing mechanism for H3R antagonist-induced inhibition of alcohol reward is the possible modulation of postsynaptic dopamine receptor signaling in striatum and nucleus accumbens. Accumulating evidence suggests that H3Rs form functional receptor heteromers with dopamine D1 and D2 receptors (Ferrada et al., 2008, 2009; Moreno et al., 2011) and that specific ligands that bind to one of the receptor of the heteromer, will affect the affinity and signaling of the other. Thus, it is possible that by binding to postsynaptic H3Rs in striatal areas, the H3R antagonists might interfere with the enhanced dopaminergic signaling induced by alcohol. We have measured the plasma alcohol concentrations after H3R ligand administration and found no difference compared to the corresponding controls thus ruling out the possibility that H3R ligands would alter alcohol metabolism (Nuutinen et al., 2011a).

\section{SIMILARITIES AND CONTRASTING FINDINGS WITH OTHER DRUGS OF ABUSE}

Mechanisms leading to addictive behaviors are thought to be common for all drugs of abuse. In line with the inhibitory role of histamine in alcohol-induce place preference, a study using $\mathrm{H} 1$ receptor knockout mice found a stronger methamphetamineinduced CPP than in wild type controls (Takino et al., 2009) and $\mathrm{H} 3 \mathrm{R}$ antagonists thioperamide and clobenprobit reduced amphetamine self-administration in rats (Munzar et al., 2004). In contrast to our alcohol study the CPP for methamphetamine was not 
different in histamine H3R KO mice compared to the control animals (Okuda et al., 2009). However, the authors used a biased CPP design (by using one conditioning cue) and place preference was scored by comparing pre-conditioning and post-conditioning times. In our laboratory we use two distinct conditioning cues that are neutral to the mice meaning that they do not prefer either one of them initially (unbiased design). This is to prevent e.g., the anxiolytic effect of the drug used that could lead to false-positive result (Cunningham et al., 2003). Further, studies have shown that mice change their preference during the conditioning period without any reinforcing drugs, so in our paradigm place preference is scored as time spent in one of the sides of the chamber during the preference test following the conditioning days (Tzschentke, 2007). We compare this time between two groups that received alcohol paired with separate cues. Significant difference between the subgroups indicates place preference.

Studies on histamine's role in morphine dependence are few but support the inhibitory role of histamine in reward and reinforcement. Morphine-induced CPP was attenuated by increasing histamine levels with $\mathrm{L}$-histidine and potentiated by inhibiting histamine synthesis with $\alpha$-fluoromethyl histidine in mice (Suzuki et al., 1995; Table 2). H2 receptor antagonist zolantadine potentiated morphine-induced CPP but also induced place preference alone accompanied by an increase in dopamine turnover suggesting that it has other targets, possibly dopamine transporter, in addition to H2Rs. In accordance with our data with alcohol, the morphine-induced place preference was stronger in $\mathrm{HDC} \mathrm{KO}$ mice (Gong et al., 2010).

Studies on psychostimulants (cocaine, methamphetamine) are not in line with the suggested inhibitory role of histamine in addictive behaviors. In contrast to other findings in $\mathrm{HDC} \mathrm{KO}$ mice (Gong et al., 2010; Nuutinen et al., 2010), no difference in cocaine-induced CPP was found between the HDC KO and wild type mice (Brabant et al., 2007). Further, a pretreatment with an H3R antagonist thioperamide enhanced cocaine's effects by inducing place preference in mice with a cocaine dose that did not induce CPP alone (Brabant et al., 2005). However, thioperamide was later found to inhibit cocaine metabolism via inhibition of liver CYP450 enzymes (Brabant et al., 2009). Amphetamine is also metabolized via liver CYP-450 enzymes. Thus, the observations that

\section{REFERENCES}

Addolorato, G., Caputo, F., Capristo, E., Domenicali, M., Bernardi, M., Janiri, L., Agabio, R., Colombo, G., Gessa, G. L., and Gasbarrini, G. (2002). Baclofen efficacy in reducing alcohol craving and intake: a preliminary double-blind randomized controlled study. Alcohol Alcohol. 37, 504-508.

Ahtee, L., and Eriksson, K. (1973). Regional distribution of brain 5hydroxytryptamine in rat strains selected for their alcohol intake. Ann. N. Y. Acad. Sci. 215, 126-134.

Ahtee, L., and Eriksson, K. (1975). Dopamine and noradrenaline content in the brain of rat strains

H3R antagonists thioperamide and clobenpropit potentiate selfadministration and discrimination of methamphetamine might be due to inhibition of methamphetamine metabolism by these imidazole-based H3R antagonists (Munzar et al., 1998, 2004). Further studies with non-imidazole-based H3R compounds and with knockout/transgenic animal models are needed to reveal the role of $\mathrm{H} 3 \mathrm{R}$ in psychostimulant-induced reward and reinforcement.

Numerous studies on first generation H1R antagonists support the inhibitory role of histamine in reward (for a review see Brabant et al., 2010). However, these drugs have many targets in addition to H1Rs such as muscarinic receptors and more importantly, the dopamine transporter (Shishido et al., 1991; Oishi et al., 1994). Thus, it is most probably the inhibition of dopamine uptake rather than H1R blockade that explains why H1R blockers can cause per se or increase behavioral effects typically induced by addictive substances.

\section{CONCLUSIONS}

There is accumulating evidence from alcohol drinking and place preference studies suggesting that alcohol reward could be decreased by treatment with H3R antagonists. More studies are still needed to test the potential of H3R antagonists to prevent alcohol withdrawal symptoms or relapse. Cellular and molecular mechanistic studies are also of great importance in order to more widely increase our understanding of the complex role of $\mathrm{H} 3 \mathrm{R}$ in addictive behaviors. Studies on alcohol and morphine suggest that targeting brain H3Rs could be a potential means to treat drug addiction. However, due to conflicting findings with $\mathrm{H} 3 \mathrm{R}$ antagonists in psychostimulant addiction-related behaviors, more preclinical studies are needed to really show whether H3R antagonist would be beneficial in other types of drug addictions. One of the key questions to be solved is related to the possible differential expression of H3R in different dopaminergic neurons, and analysis of direct vs. indirect effects of H3R on dopamine release. Whereas it seems that histamine $\mathrm{H} 3$ receptor is a key element in alcohol drinking and place preference, the role of histamine in these behaviors is still unclear. The relative importance of histamine and other transmitters regulated by $\mathrm{H} 3$ receptor antagonism in several alcohol-related behaviors remains to be studied using specific tools.

H., Lin, J. S., Jatlow, P., Picciotto, M. R., and Tirelli, E. (2009). Effects of the $\mathrm{H} 3$ receptor inverse agonist thioperamide on cocaineinduced locomotion in mice: role of the histaminergic system and potential pharmacokinetic interactions. Psychopharmacology (Berl.) 202, 673-687.

Brabant, C., Alleva, L., Quertemont, E., and Tirelli, E. (2010). Involvement of the brain histaminergic system in addiction and addiction-related behaviors: A comprehensive review with emphasis on the potential therapeutic use of histaminergic compounds in drug dependence. Prog. Neurobiol. 92, 421-441.
Brabant, C., Charlier, Y., Quertemont, E., and Tirelli, E. (2005). The H3 antagonist thioperamide reveals conditioned preference for a context associated with an inactive small dose of cocaine in C57BL/6J mice. Behav. Brain Res. 160, 161-168.

Brabant, C., Quertemont, E., Anaclet, C., Lin, J. S., Ohtsu, H., and Tirelli, E. (2007). The psychostimulant and rewarding effects of cocaine in histidine decarboxylase knockout mice do not support the hypothesis of an inhibitory function of histamine on reward. Psychopharmacology (Berl.) 190, 251-263. 
Brioni, J. D., Esbenshade, T. A., Garrison, T. R., Bitner, S. R., and Cowart, M. D. (2011). Discovery of histamine $\mathrm{H} 3$ antagonists for the treatment of cognitive disorders and Alzheimer's disease. J. Pharmacol. Exp. Ther. 336, 38-46.

Cloninger, C. R., Sigvardsson, S., and Bohman, M. (1988). Childhood personality predicts alcohol abuse in young adults. Alcohol. Clin. Exp. Res. 12, 494-505.

Cowart, M., Pratt, J. K., Stewart, A. O., Bennani, Y. L., Esbenshade, T. A., and Hancock, A. A. (2004). A new class of potent non-imidazole $\mathrm{H}(3)$ antagonists: 2-aminoethylbenzofurans. Bioorg. Med. Chem. Lett. 14, 689-693.

Cunningham, C. L., Ferree, N. K., and Howard, M. A. (2003). Apparatus bias and place conditioning with ethanol in mice. Psychopharmacology (Berl.) 170, 409-422.

Cunningham, C. L., Gremel, C. M., and Groblewski, P. A. (2006). Druginduced conditioned place preference and aversion in mice. Nat. Protoc. 1, 1662-1670.

Edwards, S., Kenna, G. A., Swift, R. M., and Leggio, L. (2011). Current and promising pharmacotherapies, and novel research target areas in the treatment of alcohol dependence: a review. Curr. Pharm. Des. 17, 1323-1332.

Eriksson, K. (1968). Genetic selection for voluntary alcohol consumption in the albino rat. Science 159, 739-741.

Esbenshade, T. A., Fox, G. B., Krueger, K. M., Miller, T. R., Kang, C. H., Denny, L. I., Witte, D. G., Yao, B. B., Pan, L., Wetter, J., Marsh, K., Bennani, Y. L., Cowart, M. D., Sullivan, J. P., and Hancock, A. A. (2005). Pharmacological properties of ABT-239 [4-(2-\{2[(2R)-2-Methylpyrrolidinyl] ethyl $\}$ benzofuran-5-yl)benzonitrile]: I. Potent and selective histamine $\mathrm{H} 3$ receptor antagonist with drug-like properties. J. Pharmacol. Exp. Ther. 313, 165-175.

Ferrada, C., Ferre, S., Casado, V., Cortes, A., Justinova, Z., Barnes, C., Canela, E. I., Goldberg, S. R., Leurs, R., Lluis, C., and Franco, R. (2008). Interactions between histamine $\mathrm{H} 3$ and dopamine D2 receptors and the implications for striatal function. Neuropharmacology 55, 190-197.

Ferrada, C., Moreno, E., Casado, V., Bongers, G., Cortes, A., Mallol, J., Canela, E. I., Leurs, R., Ferré, S., Lluís, C., and Franco, R. (2009). Marked changes in signal transduction upon heteromerization of dopamine D1 and histamine $\mathrm{H} 3$ receptors. $\mathrm{Br}$. J. Pharmacol. 157, 64-75.

Fogel, W. A., Michelsen, K. A., Granerus, G., Sasiak, K., Andrzejewski, W., Panula, P., and Maslinski, C. (2002). Neuronal storage of histamine in the brain and tele-methylimidazoleacetic acid excretion in portocaval shunted rats. J. Neurochem. 80, 375-382.

Fox, G. B., Esbenshade, T. A., Pan, J. B., Radek, R. J., Krueger, K. M., Yao, B. B., Browman, K. E., Buckley, M. J., Ballard, M. E., Komater, V. A., Miner, H., Zhang, M., Faghih, R., Rueter, L. E., Bitner, R. S., Drescher, K. U., Wetter, J., Marsh, K., Lemaire, M., Porsolt, R. D., Bennani, Y. L., Sullivan, J. P., Cowart, M. D., Decker, M. W., and Hancock, A. A. (2005). Pharmacological properties of ABT-239 [4-(2-\{2[(2R)-2-Methylpyrrolidinyl] ethyl\}benzofuran-5-yl)benzonitrile]: II. Neurophysiological characterization and broad preclinical efficacy in cognition and schizophrenia of a potent and selective histamine $\mathrm{H} 3$ receptor antagonist. J. Pharmacol. Exp. Ther. 313, 176-190.

Galici, R., Rezvani, A. H., Aluisio, L., Lord, B., Levin, E. D., Fraser, I., Boggs, J., Welty, N., Shoblock, J. R., Motley, S. T., Letavic, M. A., Carruthers, N. I., Dugovic, C., Lovenberg, T. W., and Bonaventure, P. (2011). JNJ-39220675, a novel selective histamine $\mathrm{H}(3)$ receptor antagonist, reduces the abuse-related effects of alcohol in rats. Psychopharmacology (Berl) 214, 829-841.

Garbarg, M., Barbin, G., Rodergas, E., and Schwartz, J. C. (1980). Inhibition of histamine synthesis in brain by alpha-fluoromethylhistidine, a new irreversible inhibitor: in vitro and in vivo studies. J. Neurochem. 35, 1045-1052.

Giannoni, P., Medhurst, A. D., Passani, M. B., Giovannini, M. G., Ballini, C., Corte, L. D., and Blandina, P. (2010). Regional differential effects of the novel histamine H3 receptor antagonist 6-[(3cyclobutyl-2,3,4,5-tetrahydro1H-3-benzazepin-7-yl)oxy]-Nmethyl-3-p yridinecarboxamide hydrochloride (GSK189254) on histamine release in the central nervous system of freely moving rats. J. Pharmacol. Exp. Ther. 332, 164-172.

Giannoni, P., Passani, M. B., Nosi, D., Chazot, P. L., Shenton, F. C., Medhurst, A. D., Munari, L., and Blandina, P. (2009). Heterogeneity of histaminergic neurons in the tuberomammillary nucleus of the rat. Eur. J. Neurosci. 29, 2363-2374.

Goldstein, D. B., and Kakihana, R. (1977). Circadian rhythms of ethanol consumption by mice: a simple computer analysis for chronopharmacology. Psychopharmacology (Berl.) 52, 41-45.

Gong, Y. X., Zhang, W. P., Shou, W. T., Zhong, K., and Chen, Z. (2010). Morphine induces conditioned place preference behavior in histidine decarboxylase knockout mice. Neurosci. Lett. 468, 115-119.

Green, A. S., and Grahame, N. J. (2008). Ethanol drinking in rodents: is freechoice drinking related to the reinforcing effects of ethanol? Alcohol 42, $1-11$.

Haas, H., and Panula, P. (2003). The role of histamine and the tuberomamillary nucleus in the nervous system. Nat. Rev. Neurosci. 4, 121-130.

Ireland-Denny, L., Parihar, A. S., Miller, T. R., Kang, C. H., Krueger, K. M., Esbenshade, T. A., and Hancock, A. A. (2001). Species-related pharmacological heterogeneity of histamine H(3) receptors. Eur. J. Pharmacol. 433, 141-150.

Jin, C. Y., and Panula, P. (2005). The laminar histamine receptor system in human prefrontal cortex suggests multiple levels of histaminergic regulation. Neuroscience 132, 137-149.

Johnson, B. A., Ait-Daoud, N., Bowden, C. L., DiClemente, C. C., Roache, J. D., Lawson, K., Javors, M. A., and Ma, J. Z. (2003). Oral topiramate for treatment of alcohol dependence: a randomised controlled trial. Lancet 361, 1677-1685.

Kalivas, P. W., and Volkow, N. D. (2011). New medications for drug addiction hiding in glutamatergic neuroplasticity. Mol. Psychiatry 16, 974-986.

Kitanaka, N., Kitanaka, J., Nishiguchi, M., Kinoshita, H., Ouchi, H., Minami, T., Hishida, S., and Takemura, M. (2004). Decreased histamine-stimulated phosphoinositide hydrolysis in the cerebral cortex of a rat line selectively bred for high alcohol preference. Neurochem. Res. 29, 1431-1436.

Kollonitsch, J., Perkins, L. M., Patchett, A. A., Doldouras, G. A., Marburg, S., Duggan, D. E., Maycock, A. L., and Aster, S. D. (1978). Selective inhibitors of biosynthesis of aminergic neurotransmitters. Nature 274 906-908.

Koob, G. F., and Volkow, N. D. (2010). Neurocircuitry of addiction. Neuropsychopharmacology 35, 217-238.

Kraus, T., Schanze, A., Groschl, M., Bayerlein, K., Hillemacher, T., Reulbach, U., Kornhuber, J., and Bleich, S.
(2005). Ghrelin levels are increased in alcoholism. Alcohol. Clin. Exp. Res. 29, 2154-2157.

Kuhne, S., Wijtmans, M., Lim, H. D., Leurs, R., and de Esch, I. J. (2011) Several down, a few to go: histamine $\mathrm{H}(3)$ receptor ligands making the final push towards the market? Expert Opin. Investig. Drugs 20, 1629-1648.

Lasseter, H. C., Xie, X., Ramirez, D. R., and Fuchs, R. A. (2010). Prefrontal cortical regulation of drug seeking in animal models of drug relapse. Curr. Top. Behav. Neurosci. 3, 101-117.

Ligneau, X., Perrin, D., Landais, L., Camelin, J. C., Calmels, T. P., Berrebi-Bertrand, I., Lecomte, J. M., Parmentier, R., Anaclet, C., Lin, J. S., Bertaina-Anglade, V., la Rochelle, C. D., d'Aniello, F., Rouleau, A., Gbahou, F., Arrang, J. M., Ganellin, C. R., Stark, H., Schunack, W., and Schwartz, J. C. (2007). BF2.649 [1-\{3-[3-(4-Chloro phenyl)propoxy]propyl $\}$ piperidine, hydrochloride], a nonimidazole inverse agonist/antagonist at the human histamine $\mathrm{H} 3$ receptor: Preclinical pharmacology. J. Pharmacol. Exp. Ther. 320, 365-375.

Lintunen, M., Hyytia, P., Sallmen, T., Karlstedt, K., Tuomisto, L., Leurs, R., Kiianmaa, K., Korpi, E. R., and Panula, P. (2001). Increased brain histamine in an alcohol-preferring rat line and modulation of ethanol consumption by $\mathrm{H}(3)$ receptor mechanisms. FASEB J. 15, 1074-1076.

Lintunen, M., Raatesalmi, K., Sallmen, T., Anichtchik, O., Karlstedt, K., Kaslin, J., Kiianmaa, K., Korpi, E. R., and Panula, P. (2002). Low brain histamine content affects ethanolinduced motor impairment. Neurobiol. Dis. 9, 94-105.

Lowery, E. G., and Thiele, T. E. (2010). Pre-clinical evidence that corticotropin-releasing factor (CRF) receptor antagonists are promising targets for pharmacological treatment of alcoholism. CNS Neurol. Disord. Drug Targets 9, 77-86.

Lozeva, V., Tuomisto, L., Tarhanen, J., and Butterworth, R. F. (2003). Increased concentrations of histamine and its metabolite, tele-methylhistamine and downregulation of histamine $\mathrm{H} 3$ receptor sites in autopsied brain tissue from cirrhotic patients who died in hepatic coma. J. Hepatol. 39, 522-527.

Maccioni, P., Colombo, G., and Carai, M. A. (2010). Blockade of the cannabinoid CB1 receptor and alcohol dependence: preclinical evidence and preliminary clinical data. CNS 
Neurol. Disord. Drug Targets 9, 55-59.

McCormick, D. A., and Williamson, A. (1989). Convergence and divergence of neurotransmitter action in human cerebral cortex. Proc. Natl. Acad. Sci. U.S.A. 86, 8098-8102.

Medhurst, A. D., Atkins, A. R., Beresford, I. J., Brackenborough, K., Briggs, M. A., Calver, A. R., Cilia, J., Cluderay, J. E., Crook, B., Davis, J. B., Davis, R. K., Davis, R. P., Dawson, L. A., Foley, A. G., Gartlon, J., Gonzalez, M. I., Heslop, T., Hirst, W. D., Jennings, C., Jones, D. N., Lacroix, L. P., Martyn, A., Ociepka, S., Ray, A., Regan, C. M., Roberts, J. C., Schogger, J., Southam, E., Stean, T. O., Trail, B. K., Upton, N., Wadsworth, G., Wald, J. A., White, T., Witherington, J., Woolley, M. L., Worby, A., and Wilson, D. M. (2007). GSK189254, a novel H3 receptor antagonist that binds to histamine $\mathrm{H} 3$ receptors in Alzheimer's disease brain and improves cognitive performance in preclinical models. J. Pharmacol. Exp. Ther. 321, 1032-1045.

Moreno, E., Hoffmann, H., GonzalezSepulveda, M., Navarro, G., Casado, V., Cortes, A., Mallol, J., Vignes, M., McCormick, P. J., Canela, E. I., Lluís, C., Moratalla, R., Ferré, S., Ortiz, J, and Franco, R. (2011). Dopamine D1-histamine H3 receptor heteromers provide a selective link to the map-kinase signalling in gabaergic neurons of the direct striatal pathway. J. Biol. Chem. 286, 5846-5854.

Munzar, P., Nosal, R., and Goldberg, S. R. (1998). Potentiation of the discriminative-stimulus effects of methamphetamine by the histamine $\mathrm{H} 3$ receptor antagonist thioperamide in rats. Eur. J. Pharmacol. 363, 93-101.

Munzar, P., Tanda, G., Justinova, Z., and Goldberg, S. R.
(2004). Histamine H3 receptor antagonists potentiate methamphetamine self-administration and methamphetamine-induced accumbal dopamine release. Neuropsychopharmacology 29, 705-717.

Nuutinen, S., Karlstedt, K., AittaAho, T., Korpi, E. R., and Panula, P. (2010). Histamine and $\mathrm{H} 3$ receptor-dependent mechanisms regulate ethanol stimulation and conditioned place preference in mice. Psychopharmacology (Berl.) 208, 75-86.

Nuutinen, S., Lintunen, M., Vanhanen, J., Ojala, T., Rozov, S., and Panula, P. (2011a). Evidence for the role of histamine $\mathrm{H} 3$ receptor in alcohol consumption and alcohol reward in mice. Neuropsychopharmacology 36, 2030-2040.

Nuutinen, S., Vanhanen, J., Pigni, M. C., and Panula, P. (2011b). Effects of histamine $\mathrm{H} 3$ receptor ligands on the rewarding, stimulant and motor-impairing effects of ethanol in DBA/2J mice. Neuropharmacology 60, 1193-1199.

Oishi, R., Shishido, S., Yamori, M., and Saeki, K. (1994). Comparison of the effects of eleven histamine H1-receptor antagonists on monoamine turnover in the mouse brain. Naunyn Schmiedebergs Arch. Pharmacol. 349, 140-144.

Okuda, T., Zhang, D., Shao, H., Okamura, N., Takino, N., Iwamura, T., Sakurai, E., Yoshikawa, T., and Yanai, K. (2009). Methamphetamine- and 3,4methylenedioxymethamphetamineinduced behavioral changes in histamine H3-receptor knockout mice. J. Pharmacol. Sci. 111, 167-174.

Panula, P., Pirvola, U., Auvinen, S., and Airaksinen, M. S. (1989). Histamine-immunoreactive nerve fibers in the rat brain. Neuroscience $28,585-610$.

Pohorecky, L. A. (1991). Stress and alcohol interaction: an update of human research. Alcohol. Clin. Exp. Res. 15, 438-459.

Rhodes, J. S., Best, K., Belknap, J. K., Finn, D. A., and Crabbe, J. C. (2005) Evaluation of a simple model of ethanol drinking to intoxication in C57BL/6J mice. Physiol. Behav. 84 53-63.

Rusi, M., Eriksson, K., and Maki, J. (1977). Genetic differences in the susceptibility to acute ethanol intoxication in selected rat strains. $A d v$ Exp. Med. Biol. 85A, 97-109.

Schlicker, E., Malinowska, B., Kathmann, M., and Gothert, M. (1994). Modulation of neurotransmitter release via histamine $\mathrm{H} 3$ heteroreceptors. Fundam. Clin. Pharmacol. 8 , 128-137.

Schnell, D., Strasser, A., and Seifert, R. (2010). Comparison of the pharmacological properties of human and rat histamine $\mathrm{H} 3$ receptors. Biochem. Pharmacol. 80, 1437-1449.

Sellers, E. M., Toneatto, T., Romach, M. K., Somer, G. R., Sobell, L. C., and Sobell, M. B. (1994). Clinical efficacy of the 5-HT3 antagonist ondansetron in alcohol abuse and dependence. Alcohol. Clin. Exp. Res. $18,879-885$.

Shishido, S., Oishi, R., and Saeki, K. (1991). In vivo effects of some histamine H1-receptor antagonists on monoamine metabolism in the mouse brain. Naunyn Schmiedebergs Arch. Pharmacol. 343, 185-189.

Suzuki, T., Takamori, K., Misawa, M., and Onodera, K. (1995). Effects of the histaminergic system on the morphine-induced conditioned place preference in mice. Brain Res. $675,195-202$
Takino, N., Sakurai, E., Kuramasu, A., Okamura, N., and Yanai, K. (2009). Roles of the histaminergic neurotransmission on methamphetamine-induced locomotor sensitization and reward: a study of receptors gene knockout mice. Int. Rev. Neurobiol. 85, 109-116.

Thorsell, A., Karlsson, R. M., and Heilig, M. (2006). NPY in alcoholism and psychiatric disorders. EXS, 95, 183-192.

Tzschentke, T. M. (2007). Measuring reward with the conditioned place preference $(\mathrm{CPP})$ paradigm: update of the last decade. Addict. Biol. 12, 227-462.

Verdiere, M., Rose, C., and Schwartz, J. C. (1975). Synthesis and release of histamine studied on slices from rat hypothalamus. Eur. J. Pharmacol. 34 157-168.

Conflict of Interest Statement: S. Nuutinen, J. Vanhanen, and T. Mäki declare no conflict of interest. P. Panula has received lecture compensation from Abbott Laboratories.

Received: 10 March 2012; accepted: 26 April 2012; published online: 18 May 2012.

Citation: Nuutinen S, Vanhanen J, Mäki T and Panula P (2012) Histamine H3 receptor: a novel therapeutic target in alcohol dependence? Front. Syst. Neurosci. 6:36. doi: 10.3389/fnsys.2012.00036

Copyright $\odot 2012$ Nuutinen, Vanhanen, Mäki and Panula. This is an open-access article distributed under the terms of the Creative Commons Attribution Non Commercial License, which permits noncommercial use, distribution, and reproduction in other forums, provided the original authors and source are credited. 